\title{
Public opinion on freedom of religion (and its limitations) in penitentiary establishments in the light of international regulations
}

A Polish perspective ${ }^{\star}$

DOI: https://doi.org/10.30664/ar.111029

(c)(1) Attribution 4.0 International (CC BY 4.0)

$\mathrm{T}$ he issue of religious freedom while serving a sentence of imprisonment often occupies scientists from around the world. Basically, they agree that a prisoner, regardless of the act for which he or she has been convicted, has the right to religious freedom. Problems are posed, however, by the question of delimiting this freedom, especially at the level of the right to practise a chosen religion during prison isolation. The decisions of international tribunals and national courts are not uniform owing to the generality of the rules governing this issue. The initial research question that we pose is this: how does society perceive the right to religious freedom in prisons? Does a convict have the right to demand respect for the rules of his or her religion regarding diet, clothes, appearance and participation in religious services? We look for answers to these questions in research conducted in Polish society, one that is confronted by international regulations.

\section{Introduction}

In a prayer of the Divine Office recited during the feast of the Most Holy Virgin Mary, Queen of Poland (3 May), the faithful of the Roman Catholic Church pray to the Lord through the intercession of the

* The article is the result of research undertaken as part of the research project financed by the National Science Centre (Poland), granted on the basis of decision no. $2018 / 31 / \mathrm{B} / \mathrm{HS}_{5} / 02233$. patroness, the Virgin Mary, that 'religion continually enjoy freedom and the homeland flourish in peace.' It is not entirely clear whether the notion of 'religion' must be understood in this case as meaning simply Christianity or only one of its denominations. This understatement seems quite significant and, paradoxically, is closely linked to our study.

In Poland, where, according to the selfdeclaration of faith, a vast majority of citizens (90 per cent) define themselves as believers (see Centrum Badania Opinii Społecznej 2020), the support for freedom of religion still seems to be very strong. Poles have considerable understanding of manifesting one's religion either alone or in community and in public or private. The public is quite tolerant, for instance, of the presence of religious symbols in public space, but it is unfortunate that this holds true only for the prevalent Roman Catholic denomination. The question of the universal acceptance of the equal presence of other religions in the public space, even if it is only the great ones such as Judaism, Islam and Buddhism, ends with a big question mark.

Against this background, even more doubts arise in the case where freedom of religion is confronted with a regime 
specific to authoritarian institutions. This issue occupies researchers from all over the world (Becci and Dubler 2017; Beckford and Gilliat 2005). They largely agree that a prisoner should have the right to freedom of religion regardless of the act for which he or she was convicted. The crux of the matter giving rise to heated discussions is setting the limits to this freedom (Raza 2020; Temperman 2018; Tiedemann 2012).

The decisions of international tribunals and national courts are not uniform in this matter. Often, there is no possibility of reconstructing the background of case law relating to any national organisation (Martínez-Torrón 2012; Slotte 2020). This is becasue the provisions regarding freedom of religion are often far from precise and the level of their generalization leads prison administrators to make decisions on an ad hoc basis. The same is true of the evaluations by audit bodies, including, in particular, courts.

Nowadays, it is undisputed that the process of making and applying the law should be in line with social expectations because in this way the approval and effectiveness of the norms of a given normative system increase. The legislation of civilized states must also not ignore the standards established by the provisions of international law regarding human and civil rights and freedoms. Given that the legislators of different states make legislative decisions influenced by impulses generated by public opinion, it cannot be ruled out that public opinion will also have an impact on a judge's decision. As a result, it is of the utmost importance to establish how the public perceives the issue of freedom of religion during imprisonment. In other words, how much freedom of religion should be given in penitentiary establishments? This is the research problem addressed in this publication. The findings of this study will be preceded by an analysis of the state of law. The analysis will also include acts of international law and, by way of illustration, the Polish regulations as a necessary specification and implementation of treaty regulations. Furthermore, we will attempt to address the issue of whether it is appropriate or inappropriate to take into account public opinion in the process of creating and applying the norms of executive criminal law.

Because of the pandemic, the study was carried out by means of an anonymous and voluntary online survey consisting of eighteen questions and the respondent's particulars. The survey was completed by 307 persons in total. We are aware of the advantages and disadvantages of this type of study, but we believe that the research problem did not require a random sampling method, which is the main drawback of online surveys. In qualitative research, what is more important than random sampling that enables wide generalization is that the respondents meet certain criteria of purposive sampling and an in-depth analysis and explanation of individual perspectives are possible (Batorski and Olcoń-Kubicka 2006; Kaczmarczyk 2018). At the same time, our study revealed the undisputed advantage of online surveys - an almost unlimited opportunity for free response to open-ended questions. The lack of time and technical constraints resulted in a relatively large number of replies to additional and optional open-ended questions (Hagan 2018: 118-19).

The computer-assisted web-based interview (CAWI) was of an exploratory and descriptive nature. Criminological studies most frequently refer to quantitative or qualitative research; however, mention is increasingly being made of the possibility of combining these two approaches. As early as the 1970s, the strategy of using different methods in one research study was 
introduced to social sciences (UrbaniakZając 2018: 122). After several decades, John Ward Creswell and John David Creswell (Creswell and Creswell 2018) noted that mixed-methods research is an expression of progress, another step forward that uses the advantages of both qualitative and quantitative research. This view is shared by the authors of this article - a great number of open-ended questions facilitating spontaneous expression makes the survey functionally similar to the structured-interview questionnaire. The sampling was non-probabilistic and was based on so-called respondent availability. This allowed for a generalization of the results to the entire population, with a significant range of error. It is therefore not possible to draw statistical conclusions on the entire population, but the research subject, i.e. the opinions of internet users on the issue of freedom of religion in penitentiary establishments and the researchers' expertise in this area, allowed for the selection of a fairly representative sample, selected exactly from among internet users (Miszczak and Walasek 2013: 102). Even though this research method involves the risk of a lack of control over the research group, with a great deal of caution, it may be a source of useful information (Babbie 2016).

The article does not contain respondents' variables (sex, age, etc.) because no dependencies based on them are presented. In this case, no statistical analysis was conducted since the study focused exclusively on the respondents' opinions on the issue of freedom of religion in prisons.

The article uses a diverse methodology - an analysis of the survey results is compared with the results of an analysis of legal texts carried out using a linguistic-analysis method (formal-dogmatic and languagelogical). It is an empirical legal method arising from the theoretical achievements of legal sciences. This method was selected because studies of this type broaden the knowledge of law and they most frequently contribute to an improvement of positive law by making an assessment of how positive law is applied in social practice and, as a result, can put forward proposals for a modification of that law.

\section{International and Polish regulations regarding freedom of religion in penitentiary establishments}

Freedom of religion in penitentiary establishments is guaranteed by numerous legal acts, including those provided for by international law. The Convention for the Protection of Human Rights and Fundamental Freedoms (ECHR) should first be called to mind; it was opened for signature in Rome on 4 November 1950, laying down in Art. 9 that, among other things, everyone has the right to freedom of religion, which is to be subject only to such limitations as are prescribed by law and are necessary in a democratic society in the interests of public safety, for the protection of public order, health or morals, or for the protection of the rights and freedoms of others. This provision protects primarily the sphere of personal and religious beliefs of an individual - it is his or her forum internum (Nowicki 2017) - as well as the right to manifest them, including through participation in rites, in particular church services (see Kokkinakis $v$. Greece - Application no. 14307/88; judgement of the Court of Appeal in Poznań of 3 March 2016 I ACa 1042/15, Lex no. 3044449). At the same time, like many other international norms, this provision does not define the minimal scope of prisoners' rights in the area of professing and manifesting one's religious beliefs and does not provide a gradation (hierarchy) of the manifesta- 
tion of religious beliefs (Hucał 2016). Even though the state is under no obligation to meet all religious expectations of prisoners because the Convention 'does not protect every act motivated or inspired by a religion or belief', the question arises whether a certain standard of the limits of freedom of religion in the prison should, nonetheless, be ensured by the Convention.

Another international act that acknowledges the right to retain freedom of religion while in prison is the International Covenant on Civil and Political Rights (ICCPR), which in Art. 18 lays down that everyone shall have the right to freedom of thought, conscience and religion, including freedom to have or to adopt a religion or belief of his choice, and freedom, either individually or in community with others and in public or private, to manifest his religion or belief in worship, observance, practice and teaching. Art. 18 (3) ICCPR provides that freedom to manifest one's religion or beliefs may be subject only to such limitations as are prescribed by law and are necessary to protect public safety, order, health or morals, or the fundamental rights and freedoms of others. It protects primarily the sphere of personal and religious beliefs of a human person, that is to say what is customarily referred to in the literature and case-law of the European Court of Human Rights as forum internum, whereby freedom of religion and conscience includes freedom to have religious beliefs and to adopt or to reject a religion of one's choice, including freedom to manifest religion or beliefs, either individually or in community with others and in public or private (Sobczak 2012).

A fundamental act of international law ensuring freedom of religion is the European Prison Rules (hereinafter EPR). Rule 29.1 provides that prisoners' freedom of thought, conscience and religion shall be respected. The following paragraph sets out that the prison regime shall be organized so far as is practicable to allow prisoners to practise their religion and follow their beliefs, to attend services or meetings led by approved representatives of such religion or beliefs, to receive visits in private from such representatives of their religion or beliefs and to have in their possession books or literature relating to their religion or beliefs. In turn, Rule 22.1 lays down that a nutritious diet provided to prisoners shall 'take into account' their religion.

The aim of the EPR is to minimize the negative effects of imprisonment by bringing the conditions of imprisonment as close as possible to those in which a person is at liberty - the rules are formulated in such a manner as to enable the prisoner the fullest extent of responsibility for himself or herself and to prevent breaking ties with open society and its values (Płatek 2009). Further, Jerzy Nikołajew is right to argue that it was the first time that the recommendations so strongly emphasized the significance of respect for prisoners in the area of their religious rights, recognizing attendance at services, meetings led by approved representatives of their religion or beliefs, receiving visits in private from representatives of their religion or beliefs and having in their possession books or literature relating to their religion or beliefs as religious practices (Nikołajew 2013).

Although the EPR are only recommendations and their significance lies in recommending that the penitentiary systems of countries in our part of the world comply with the principles and values that are important in the circle of European civilization, they make use of a considerable variety of measures aimed at enforcing and controlling compliance (Szymanowski and Migdał 2014), including reporting procedures, the possibility of bringing a case to 
court under the applicable legal order of the Council of Europe member states and reports of the European Committee for the Prevention of Torture and Inhuman or Degrading Treatment or Punishment (CPT). Consequently, states should make efforts to comply with the standards contained therein. The EPR contain the minimum standards and were designed to protect prisoners against ill-treatment - being difficult to implement from the beginning, they were only a starting point, and not, as was once believed, a satisfactory aim or 'the finish line' (Płatek 2008).

Overall, the basic three acts of international law guarantee freedom of religion at a similar level - they declare the right to freedom of conscience and religion as well as to participate in religious practices. At the same time, both the ECHR and ICCPR foresee similar premises for the limitation of the sphere of freedom of religion - it may occur only by means of statute and once the additional conditions related to the fulfilment of the requirement of necessity are met (e.g. where it is necessary to protect order, health and morals). The EPR were built on slightly different principles, declaring respect for the freedom of thought, conscience and religion of prisoners and efforts to reconcile to the extent possible the prison regime with the participation in religious practices and services, and, consequently, not foreseeing the premises for limiting the rights of prisoners in this respect. This follows from the abovementioned recognition of the EPR as a starting point for a discussion on respecting this sphere of prisoners' lives.

There is no doubt that the general nature of international regulations requires that the limitation of freedom of religion be clarified by national law. The question thus arises as to the scope of the regulation of freedom of religion of persons placed in Polish penitentiary establishments and respect for the above-mentioned elementary rights of prisoners that are enshrined in international law.

The basic and most important legal act governing this area is the Constitution of the Republic of Poland, which in Art. 53 (1) prescribes that freedom of conscience and religion shall be ensured for everyone. Further, Art. 53 (2) states that freedom of religion shall include the freedom to profess or accept a religion by personal choice as well as to manifest such religion either alone or in community with others and in public or private, by worship, prayer, observance, practice and teaching. Freedom of religion shall also include the possession of temples and other places of worship, depending on the needs of believers and the right of individuals to benefit from religious assistance, wherever they may be.

In the light of Art. 53 of the Polish Constitution, the entity obliged to guarantee the individual the possibility of free exercise of his or her freedom of conscience and religion is the state. The duties of the state are not only of a negative nature (prohibition against violating the freedom), but also of a positive nature (a duty of protection where the freedom under analysis is violated by other individuals). The subject of freedom of conscience and religion is 'everyone', to be understood as every natural person, regardless of his or her nationality. It is one of the basic personal freedoms strictly connected with the individual's personality and his or her need to seek and experience transcendental values.

Notably, the Polish Constitution does not provide for a possibility of limiting freedom of conscience and religion, but it allows only a limitation of the freedom of manifestation of religion. Pursuant to Art. 53 (5), the freedom to manifest religion may be limited only by means of statute and 
only where it is necessary for the defence of state security, public order, health, morals or the freedom and rights of others. It is thus clear that the above conditions meet the requirements set by acts of international law, that is ECHR, ICCPR and EPR, allowing the limitation of freedom of religion under the condition of necessity and only by statute. An act defining the scope of limitations on human and citizen freedoms and rights must not limit freedom of conscience and religion even in a state of martial law or in a state of emergency (Sitnik and Mrozek 2011).

Moreover, all limitations of the rights and freedoms decreed in the Polish Constitution must meet the conditions set out in Art. 31 (3) of the Constitution, which foresees the proportionality principle, under which any limitations on the exercise of constitutional freedoms and rights may be imposed only by statute, and only where necessary in a democratic state for the protection of its security or public order, or to protect the natural environment, health and public morals, or freedoms and rights of others. Such limitations must not violate the essence of freedoms and rights.

The scope of the rights and freedoms of persons placed in penitentiary establishments was specified in the Executive Penal Code (hereinafter EPC), which regulates the basic rights and duties of persons deprived of liberty (both in terms of serving a penalty of deprivation of liberty and as a preventive measure in the course of proceedings in the form of pre-trial detention).

The first provision ensuring the right to freedom of religion of prisoners is Art. 102 (3) EPC, under which a convicted person shall have the right, in particular, to exercise freedom of religion. This concept involves the freedom to profess or accept a religion by personal choice as well as to manifest such religion either alone or in community with others and in public or private, by worship, prayer, observance, practice and teaching (Lelental 2001). It is a general rule that does not give prisoners specific rights, but it allows for anchoring in the EPC the directives included in other legal acts. At the same time, this norm fits in with the declarations envisaged by international law because of its lack of specification of any measurable rights or limitations and the fact that it confines itself to the general guarantee of rights of convicted persons in this respect.

Pursuant to Art. 104 EPC, the exercise by the convicted person of his or her rights should take place in a manner that does not violate the rights of other persons and does not interfere with the order established in the penitentiary establishment. Moreover, the exercise of freedom of religion must not violate the principles of tolerance or disturb the established order in the penitentiary establishment (106 \$3 EPC). The latter provision lays down the principle of religious tolerance, forming the basis of the peaceful exercise of freedom of religion in the prison.

The rights of convicted persons are specified in Art. 106 EPC under which a convicted person shall have the right to perform religious practices and benefit from religious services and to participate directly in services held in the prison on feast days and listen to services broadcast by the mass media, as well as to have books, literature and objects necessary for this purpose. Although the indicated provision ensures the right of convicted persons to particular religious practices and services, it does not provide a minimum amount to be guaranteed to a convicted person in this respect, for instance, the right to participate in at least one service per month or during feast days if such services are not held in the prison on feast days. This means, in 
essence, that the other religious practices and services have not been regulated on the statutory level, in particular, their minimum availability for convicted persons (Sitarz and Jaworska-Wieloch 2017).

Pursuant to Art. $109 \$ 1$ EPC, the diet provided to a convicted person in the prison or a detention centre should, as far as possible, be adapted to his or her religious requirements. The absolute requirement to adjust to the nutritional conditions recommended by a particular denomination is not decreed in the legal order, despite the fact that adherence to certain rules of nutrition can be seen as a manifestation of practising religion. Moreover, Art. 110a $\$ 1$ EPC lays down that a convicted person shall have the right to possess in the cell, among other things, objects of religious worship. The Code does not define in detail what is meant by the concept of objects of religious worship (Sitarz et al. 2021).

The guarantees of the rights and freedom of religion of convicted persons may be subject to further limitations as a result of Art. $247 \$ 1$ EPC, which provides that in cases justified by special sanitary or health reasons or a serious security threat, the governor of a prison or a detention centre may suspend or limit, inter alia, holding services and rendering religious services. This provision was widely used in Polish prisons in connection with the introduction of a state of pandemic. The limitations of the rights defined above may therefore apply to holding services and rendering religious services, with other forms of expression of one's freedom of religion not being subject to any limitations.

Further specification of the rights of convicted persons was laid down in a Regulation of the Minister of Justice of 2 September 2003 on the detailed rules for the performance of religious practices and the use of religious services in penitentiary establishments and detention centres (Official Journal of Laws of 2003, no. 159, pos. 1546). This act gives convicted persons the right to participate in services and meetings, also face to face, of a religious nature, taking place in a chapel or other room appropriately adapted for this purpose or a place on the premises of a penitentiary establishment or a detention centre, in accordance with the established internal rules of the establishment. The legal order does not specify the frequency of holding services in penitentiary establishments and other forms of expression of worship, constituting merely in section 2 that the internal rules in the area of performance of religious practices and use of religious services shall be determined by the governor of the establishment in cooperation with clergymen of churches or other religious associations rendering religious services in that establishment.

Such general regulations guaranteeing convicted persons the right to freedom of religion do not often stand up to specific provisions directly barring prisoners from certain behaviours. For instance, the religiously motivated need to have a beard may be questionable in the light of the provision of Art. 116a point $9 \mathrm{EPC}$, that prohibits a convicted person from changing his physical appearance in a manner that impedes his identification, in particular, by shaving or growing his hair, beard or moustache, or changing its colour, unless approved by the prison governor. Further doubts are raised in this area by Art. $116 \S 1$ point 2 EPC, which imposes on the convicted person the duty to observe personal hygiene and cleanliness of the rooms in which he or she stays. As a result, permitting a convicted person to grow a beard for religious reasons turned out to be questionable in the past (e.g. judgement of the Court of Appeal in Kraków of 24 April 2018, I ACa 1217/17, 
Lex No. 2523967), although the European Court of Human Rights indicated in a judgement of 14 June 2016 in the case of Biržietis v. Lithuania (Application no. 49304/o9), that the prohibition on growing a beard must not be justified by the need to identify prisoners or by hygienic reasons. Wearing special outfits by prisoners, such as a turban, burqa or special trousers, in accordance with the rules of particular denominations, can also be problematic owing to the limitations on the use of their own clothes by prisoners that are set out in the EPC (Art. 90 point 5 EPC, Art. $88 \$ 1$ point $10 \mathrm{EPC})$.

It is also questionable whether penitentiary establishments should provide access to all denominations. The provisions do not indicate unequivocally whether convicted persons' right to freedom of religion relates only to registered religions, although the regulations most often refer to the concept of religion, and not to the church. The EPC seems to favour the necessity of legal recognition of the denominations declared by prisoners, indicating in Art. $242 \$ 12$ EPC that the concept of 'the church' and 'other religious association' is to be understood as church or other religious association having a statutorily regulated legal situation. The introduction of such requirement is inconsistent with the case-law of the European Court of Human Rights, which reiterated in a judgement of 26 April 2016 in the case of Izzettin Doğan and others $v$. Turkey (Application no. 62649/10), that a refusal to recognize officially a particular faith amounts to denying its religious nature, leading to an interference with the applicant's right to freedom of religion as guaranteed by Art. 9 of the Convention. In similar fashion, a judgement of the Polish Constitutional Tribunal of 16 February 1999 (file no. SK 11/98, Lex no. 36175) stated that 'freedom of religion is defined very broadly in the constitutional norm, as it covers all religions and affiliation with all religious associations, and therefore it is not limited to participation in religious communities creating a formal, separate organizational structure and entered in the relevant registers kept by the public authority'. Consequently, linking the possibility of the use of religious practices and services in the prison solely with a faith recognized by the state unduly limits freedom of religion of convicted persons in a situation where the state did not want to recognize a particular religion as legal for specific, not always justified, reasons.

The provisions do not regulate the issues related to the affiliation with a specific denomination declared by a convicted person. It does not appear from any provision that the prison staff may question a convicted person as to his or her religion. Although $\$ 8$ and $\$ 9$ (2) of the Regulation of the Minister of Justice on the rules and regulations of serving a penalty of deprivation of liberty lay down that an information interview shall be conducted with a prisoner upon admission, followed by an initial interview, they make no mention of the right of the prison staff to question a convicted person on religious issues. Jerzy Nikołajew noted that the prison administration does not have data on the religious affiliation of particular prisoners and the information on the availability of clergymen of all denominations is given in the abstract (Nikołajew 2012). Even where the prison administration acquires knowledge of the religious affiliation of a convicted person, the question arises whether a declaration of a convicted person on professing a certain confession is binding for the prison administration, or whether it must be proved, or whether the prison may question that declaration. It happened at times that penitentiary units considered 
the demands of prisoners to provide a religious diet to be instrumental and made in order to obtain better-quality food or annoy the prison authorities. Ultimately, an opinion is formulated in the Polish literature that the Prison Service must not verify the professed religion or question the reliability of the declarations of convicted persons, even if they carried out several acts of conversion. A similar position can be seen in the case-law of the European Court of Human Rights, which reiterated in the case of Ivanova $v$. Bulgaria (Application no. 36207/03), of 12 April 2007, that the right to freedom of thought, conscience and religion is of paramount importance; the state is not entitled to question the fact of religious affiliation because, apart from cases of clear abuse of law, it is the prisoner's declaration that is of decisive importance in this respect. The state must therefore not check the level of faith of a convicted person, his or her commitment to the professed religion, veracity of his or her declarations, or in any other way verify the confession declared thereby, unless the denomination simply does not exist.

The provisions of Polish law appear to contain numerous guarantees of respect for the rights of convicted persons in the area of freedom of religion, although there is no normative act of sufficient hierarchy that would regulate comprehensively all the issues related to the religious practices of persons deprived of liberty. This raises the question of the compatibility of such regulations with international law that guarantees these rights on a rather general level, often not taking into account the particular limitations of the freedoms and rights of prisoners.

First, attention must be drawn to the lack of a provision that would indicate clearly since when the prison administration of a given penitentiary establishment should make endeavours to guarantee convicted persons of a given denomination permanent pastoral care. Consequently, there is no guarantee that prisoners can participate in services, in particular on religious feast days, as prescribed by the rules set out by their professed religion. This problem became particularly relevant after 1989, when Polish penitentiary units saw an increase in the number of foreigners affiliated with different churches and religious associations, including those that practically did not operate in Poland (Kwieciński 2015).

Second, doubts arise over the Polish regulations concerning the right to possess in the cell objects of religious worship and related limitations, as well as over the regulation related to taking into account religious requirements regarding meals provided to convicted persons, requiring that religious dietary recommendations are to be taken into account only 'where possible'. The European Court of Human Rights noted in the case of Jakóbski $v$. Poland that the refusal to provide a meat-free diet to a prisoner in a penitentiary establishment that would comply with the requirements of his denomination violated his right to manifest his religion by observing the rules of Buddhism, even though Mahayana Buddhism, to which by declaration the applicant belonged, only encourages vegetarianism and does not require keeping that diet (judgement of the European Court of Human Rights of 7 December 2010, Application no. 18429/06). Doubts arise also over the relations between the prohibition on changing physical appearance, duty to observe personal hygiene, lack of the possibility of wearing one's own clothes and the right to wear special outfits or garments required by some religions.

Third, even though the Polish provisions guarantee prisoners many rights and duties 
in the area of freedom of religion, as a rule, they do not define the minimum number of religious practices and services to be provided to a prisoner during imprisonment. A confrontation of these provisions with international law, which is also founded on standards with a high degree of generality, may lead to the conclusion that there is no contradiction between them. However, as the guarantees of the rights and freedoms of convicted persons declared in international law indicate that all limitations on prisoners' right to religious practices and services should be viewed with a high degree of caution, the conclusion from an analysis of their necessity, indispensability and usefulness must be that, first, not all of the limitations introduced into the Polish legal system seem to meet these requirements, and second, mere reliance on declarations without guaranteeing a certain minimum in the law, which a prisoner will be able to demand and possibly enforce, is also a violation of the respect for the right to freedom of religion of convicted persons.

Fourth, the failure to specify clearly such significant issues entails a shift in the decision-making on the final shape of freedom of religion in prisons to the administrations of penitentiary units, in particular their governors. They are to decide what practices will be made available to convicted persons and with what frequency, who will be able to benefit from them, to which canons of particular denominations the convicts will have the opportunity to adapt. Even though most of potential decisions made by prison governors can still be contested in court, firstly, not all prisoners will take advantage of such a possibility, and secondly, it will still mean resolving disputable religious issues through individual decisions that involve some degree of uncertainty and the risk of resolving the same situation in different ways instead of having this area regulated by statute in accordance with the requirements of international law.

\section{Presentation of the results of the survey}

An understanding of the religious rights and freedoms of convicted persons is an examination of only the normative part of the Polish legal order as an attempt to establish how prisoners may benefit in practical terms from religious practices and services and to what they are entitled. Another issue is whether the national regulations in this respect are consistent with the expectations of the Polish public. In other words, we sought to determine how the Polish public perceives the right to freedom of religion in penitentiary establishments, whether convicted persons should have the right to it, and if yes, to what extent, or whether, on the contrary, a penalty of deprivation of liberty entails a loss of all rights.

The respondents were first asked what serving a penalty of deprivation of liberty should entail. As many as 21.8 per cent of respondents said that serving a penalty of imprisonment should entail a loss of all freedoms/rights according to the principle that 'prison is not a holiday'. Only 10.4 per cent of respondents indicated that it should entail only the obligation to stay in prison, while maintaining other rights. The majority (62.9 per cent) of respondents believed that a balance needed to be struck between the extreme positions - certain freedoms (apart from freedom of movement) should also be limited, since a penalty of imprisonment should be severe. The remaining respondents were neutral or indicated 'others', linking their position to the need to implement social rehabilitation while serving a prison sentence, making the scope of freedom in prison dependent on the type of crime committed, or linking a penalty of imprisonment to the need to perform work 
(e.g. 'Prison is not a holiday, or work for a living').

In the question whether a prisoner should retain his or her freedom of religion and right to profess religion or worship in prison, 73.6 per cent of respondents replied positively, with 22.5 per cent allowing that possibility only partially. In contrast, 2 per cent saw no need for it.

For comparative purposes, it was important for us to know the opinion on the availability of a library in the penitentiary establishment. In this area, there was almost unanimous agreement as 96.7 per cent of respondents saw the need for it.

As many as 36.8 per cent of respondents held the opinion that access to all religions should be made available in prisons, whereas 50.5 per cent believed that this should apply to all registered religions. Interestingly, quite a few respondents (4.9 per cent) indicated that such a possibility should be limited to the dominant denomination in Poland, that is Roman Catholicism.

An interesting finding concerned the respondents' opinion on the possible necessity for prisoners to show their affiliation to a particular religion. Although 69.7 per cent said that a prisoner's declaration in this regard would be sufficient, as many as 21.2 per cent believed that this fact must be proved.

As regards the scope of religious worship in prison, only 8.8 per cent replied that it should not be limited in any manner. As many as 58.6 per cent of respondents linked limitations to organizational issues, 51.1 per cent to costs generated by such rights, and 40.4 per cent to hygienic issues. As many as 10.7 per cent linked limitations to other issues, mainly to security, the need to respect the rights of fellow prisoners, or a conflict with other duties. For instance, one respondent indicated that 'a prisoner should not use religion as an excuse to avoid work'.

A considerable number of respondents opposed the idea of constructing chapels in prisons: as many as 32.2 per cent did not see the need for it in the case of Roman Catholic chapels, but 38.1 per cent in the case of chapels of other denominations. In contrast, 43 per cent of respondents were of the opinion that it is legitimate to situate a Roman Catholic chapel in prison and 32.3 per cent supported chapels of other denominations.

The respondents were divided on the possibility of allowing prisoners to participate in the Holy Mass. Only 30 per cent of respondents allowed that possibility for all prisoners. As many as 45.6 per cent limited that possibility to non-dangerous prisoners, 28.7 per cent linked the right to participate in the Holy Mass to observance of the prison rules, but 17.3 per cent to distinctive conduct while serving a penalty of imprisonment, and 3.9 per cent to the type of committed crime. 7.3 per cent of respondents had a different view, usually related to the lack of legitimacy of holding a Holy Mass in the prison.

Interestingly, a larger number of respondents (64.8 per cent) held the view that it should be possible to observe Roman Catholic fasting in prison (abstinence from meat on Fridays or strict fasting on Ash Wednesday and Good Friday), whereas 20.8 per cent excluded that possibility. A slightly smaller number of respondents (55.7 per cent) replied that prisons should make it possible to comply with dietary restrictions of Islam and Judaism, while 23.5 per cent held the opposite view.

There was less doubt as to the right to use objects of religious worship. As many as 74.6 per cent of respondents believed that a prisoner should have the right to place a cross at his or her bed, with 19.2 
per cent excluding that possibility. In turn, 72.3 per cent indicated that a prisoner should have the right to place at his or her bed objects of other denomination with which he or she is affiliated, with 20.2 per cent disagreeing.

The majority of respondents (59.9 per cent) excluded the possibility of granting prisoners the right to wear clothing in compliance with their religious rules, while 24.4 per cent supported that possibility. The respondents showed more tolerance in the matter of wearing a beard: a plurality (41 per cent) approved of this right and 38.8 per cent did not see the need for it.

A vast majority of respondents (63.8 per cent) excluded the possibility of granting prisoners financial compensation for a violation of their freedom of religion during imprisonment; only 16.6 per cent of respondents supported the granting of such compensation.

The respondents also had the opportunity to include their own opinions on prisoners' right to freedom of religion in penitentiary establishments, and half of them took advantage of it. Most comments related to the declaration of the need to ensure freedom of religion in prisons, often with a focus on the equality of all denominations. It should be noted that reference was often made - more often than the replies to the fixed questions would indicate - to the legitimacy of limiting or abolishing the rights of prisoners in this regard, in particular where such rights would entail additional costs. Given the above, here are some selected spontaneous expressions of opinions of the respondents on freedom of religion in prisons:

Short and to the point: prison is not a holiday, but let them pray, if they need it, and believe in what they want.
Everyone can profess what they want to, but the state should not bear additional costs of different meals for every prisoner or additionally guard prisoners during mass and that is masses of different denominations. It is too much to be just. If they want to pray, let them pray in solitude.

Let them profess what they want to and pray as long as it does not interfere with the rules of the penitentiary establishment (e.g. day's schedule $v$. times for specific religious practices, as in Islam). Prisoners should not demand special treatment because of their religion.

Freedom of religion should be affected by limitations resulting from the nature of penitentiary establishment. There is no reason why anyone should be denied the right to prayer, fasting or abstaining from certain food, etc., but this does not imply the obligation to organize a chapel or allowing the possession of crosses, etc.

Prison is for serving a penalty, not for religious teaching.

Everyone has the right to faith, yet prisoners should be treated equally regardless of their religion. Prisons should focus on educational issues. Arranging prisons in a manner that fully respects all denominations of prisoners is absurd and defeats the purpose of that institution.

Faith is a private matter of every individual. It does not need to be manifested. 
Freedom of religion yes, but in a scope that does not involve the use of financial means of the state. So they can wear a cross, cap or beard, but don't build chapels or offer a special menu (if they want to go fasting, they should not eat meat). Mass on the radio in the reading room.

If someone wants to pray, let them do it within their denomination. But subjecting the day's schedule, meals or clothing to the principles of religion is too much. No religion demands inflicting harm on others (thefts, murders, battery, fraud, etc.). Since a prisoner did not obey the rules of religion during the commission of crime, there is no reason to hold a mass or other rituals for him or her. It is a prison, not a Marian sanctuary.

It is a prison, he had a chance of worship when he was free.

I think a guilty man has the right to pray for his change, but I oppose the idea of building a chapel of many denominations at the taxpayer's cost. A penalty is after all a penalty, so a prisoner should not be offered many conveniences. I am tolerant of other denominations, yet the amount of taxes we pay should not go up.

\section{Analysis of the results of the survey - discussion}

Analysing the presented survey results, the first important issue is to note that the respondents relatively often replied to survey questions with 'I don't have an opinion'. It should be recalled that the survey questions did not concern the respondents' knowledge on the rights of convicted persons, but their opinion on that issue. On the one hand, this indicates a certain maturity and reliability of persons who do not hesitate to admit that they do not have an opinion of their own. On the other hand, such replies show that the issue of freedom of religion is by no means easy. It is an issue on which two difficult problems are centred. The first problem concerns the essence of the penalty of deprivation of liberty: what the scope of limitations related to it should be, what the rights of convicted persons should be like and who is obliged to implement them. High-profile cases in Poland (murder of a six-month-old girl by her mother; see newsbeezer.com 2018) and in the world (Anders Breivik's case; see Kapotas 2017) provoke a heated discussion on the question of the adequate penalty and the manner of its execution. A study carried out in the USA shows that many respondents perceive life in prison to be unpleasant, but a high number of respondents thought that life in such a place should be harsher (Wozniak 2014). On a general or 'global' level, the American public prefers or, at the very least, accepts policies that 'get tough' with offenders. Thus, when asked, they endorse capital punishment, harsher punishments, three-strikes-and-you're-out laws, prison terms for most offenders, and lengthy incarceration for violent criminals (Cullen et al. 2000: 58). The second problem concerns freedom of religion, its significance in human life and society (Wilcox and Goldberg 2002), but above all, a confrontation of this right with the rights of other co-present and co-participant persons (e.g. persons placed in the same cell in the prison). It should be highlighted that in February 2020, the PEW Research Center released the findings of a survey called 'Spring 2019 Global Attitudes Survey' conducted via interviews in 34 countries. The survey looked at attitudes towards demo- 
cratic principles such as regular elections, free speech, free civil society and free religion. Its findings show that 76 per cent of Polish respondents deemed religious freedom to be 'very important'; however, Polish respondents ranked it eighth in importance among the nine principles of democracy included in the survey (Report 2020).

There is no longer a penitentiary system in the democratic world that deprives a convicted person of all of his or her rights (Human Rights and Prisons 2005). A separate issue is that the list of rights available to the convicted person is seen slightly differently by the public and by the state and its legislator. The findings of our survey reveal this difference. It should be reiterated that a vast majority of respondents hold the view that serving a penalty of imprisonment does not imply a loss of all human and civil rights. This means that they do not put into question Art. $4 \$_{2}$ EPC under which a convicted person shall retain civil rights and freedoms and their limitation may only result from statute and from a final judgement issued on its basis, even though they may not share the legislator's view on the detailed list of the prisoner's rights set out in Art. 102 EPC. It must be admitted that the number of those who think that persons sentenced to a penalty of imprisonment should have no rights is nonetheless very high - our survey showed it was slightly over 20 per cent of respondents. This could mean that one fifth of respondents do not agree with the modern and humanistic perception of the execution of the penalty of imprisonment. Interestingly, when answering more detailed questions, a much larger number of respondents agree to certain rights in prisons - only 2 per cent of them think that a convicted person should not retain the right to freedom of religion while serving a penalty of imprisonment.

Alongside the questions concerning freedom of religion, our survey contained a question related to the access to a library. In this way, we wanted to be able to compare the perception of a 'non-essential' right (i.e. not connected with basic or vital needs) with rights of a religious nature. This comparison is important insofar as both the access to books and the access to religious practices satisfy higher-order needs - spiritual (though of a different nature), and simultaneously, they both require considerable involvement of the state (financial and technical-organizational). Our survey showed that when granting rights to convicted persons, the respondents would be more willing to allow access to the library than to allow prisoners to practise religion. This approach can surely be linked to the ongoing secularization of society as well as a noticeable crisis of the Catholic Church in Poland (Podgórska 2021; Snyder 2021), all the more so, given that a large number of our respondents are young. According to findings by IBRiS, one of the largest polling institutes in Poland, the level of trust in the church plunged from 58 per cent of Polish Catholics in September 2016 to 40 per cent this past November, while the level of distrust jumped from 24 to 42 per cent (Snyder 2021).

It is interesting to note that the respondents are slightly more favourably disposed to the conveniences in the practice of the dominant religion in our country, as they explicitly declare in one question. The same follows from the detailed questions with a breakdown by Roman Catholicism and other religions. The respondents thus have more understanding for the necessity to comply with dietary restrictions in the case of Christians than other religions. It should be noted that dietary restrictions connected with the Roman Catholic denomination have nearly become a tradition independent of the question of faith 
in Poland. It is therefore not appropriate to eat meat in Poland on Christmas Eve, Good Friday, and even on any other Friday. This is probably why there is such a tolerance for such religious elements in prisons. This attitude is even more obvious in the case of acceptance for growing a beard. Given that a beard is in no way theologically connected with Roman Catholicism and the religious sense of having a beard is culturally alien in Poland, the tolerance for that type of religious practice is relatively low. This is in spite of the fact that having a beard does not generate any additional costs for the state, it is not a form of alleviating the prison regime or making a stay in prison more pleasant and it does not violate the rights of third persons. These replies are consistent with the attitude adopted by some of the respondents, who reject prisoners' right to practise religions that have not been registered in Poland. This attachment of the respondents to the formal side of professed religion is also visible in the belief held by over 21 per cent of them that a convicted person should prove the fact of practising a specific religion.

It is clear that the survey replies point to a link between the costs of a given religious practice to be borne by the state and the approval for such a religious practice in the penitentiary establishment. This means that building chapels in prisons comes up against considerable opposition from the public. Allowances can be made for the possession of individual objects of religious worship. The calculation of the costs of a convicted person's stay in prison (including those incurred for infrastructure, but also those related to prisoners' diet) is the subject of many political and scientific debates (Hirschberger 2020).

It must be highlighted that the respondents' spontaneous expressions can lead to the conclusion that they do not view religion as a special factor promoting social rehabilitation. They note that religious practices may be exploited. The respondents hold the view that religion should be solely an individual matter of prisoners. This approach fits in with the survey replies related to the compensation for damage arising from a violation of the right to freedom of religion - a vast majority of respondents (63.8 per cent) excluded the possibility of granting convicted persons financial satisfaction for a violation of their freedom of religion during incarceration.

Bearing in mind the information contained in the presentation of the data of this article, it must be admitted that, in essence, the respondents take a stricter stance on convicted persons' rights than it is provided for in the provisions of Polish executive criminal law and international regulations in this area. Both of these normative orders establish the right to freedom of religion as a principle and allow for its limitation only in exceptional circumstances. Notably, in the light of the above regulations, the right to freedom of religion is not a bonus for proper behaviour in the penitentiary establishment and is not confined to perpetrators of crimes of a lower severity, as called for by many of the respondents. However, both the national regulations and the conventions see the reasons for the limitation of freedom of religion in grounds similar to those reported by the respondents:

- safety of other convicted persons and respect for their rights,

- technical and organizational possibility of ensuring the performance of practices, which is in essence connected with, among other things, costs borne by the state. 


\section{Conclusions}

It is hard to disagree with the argument that 'that public opinion about punishment and corrections is multifaceted and is easily misrepresented either by brief polls or by pithy phrases like the public wants to get tough on crime' (Cullen et al. 2000: 57, italics in the original). Our survey, even though it was conducted in a narrow scope, allows for drawing some important conclusions.

The current view on serving a penalty of deprivation of penalty has changed compared to the past (Rubin 2019) - many varied functions are attributed to this penalty. Serving this penalty does not deprive a convicted person of his or her dignity, as many human rights representatives in the world emphasize.

As a rule, the Polish executive provisions regulate prisoners' rights in a fairly detailed manner: there are provisions on the number and calorific value of meals, the number of visits, baths, and the frequency of making purchases or taking walks. The provisions concerning freedom of religion are constructed in a slightly different manner: they declare the right to participate in Mass, benefit from religious services, have a personal meeting with a clergyman, and, where possible, receive a diet consistent with the professed religion. However, they do not lay down clearly whether and how often a prisoner will actually be able to exercise these rights, leaving the real extent of respect for prisoners' freedom of religion to the discretion of prison governors. The introductory part of this article also points to areas where there are no essential provisions, even of an executive nature.

We believe that the execution of a penalty of imprisonment should be regulated at the highest possible level (in the hierarchy of legal acts), in particular the issue of the limitation of particular rights. The harsh social perception of imprisonment, the necessity - according to the public opinion - to limit many human rights in prison may 'tempt' the authorities that make or, most of all, enforce the law to meet societal needs in this regard. In other words, the lack of explicit legal regulations relating to a specific religious practice with a simultaneous reluctant approach of the public to, for instance, a given religious group may result in issuing an unfavourable decision for a representative of such a group and lead to abuses. There is a considerable risk that the public exclusionary perception of 'a foreign religion', coupled with punitiveness and harshness towards 'criminals behind bars', which are quite common in Poland (Siemaszko et al. 2018), may mean that a Muslim serving a penalty of imprisonment in Poland will not be able to perform many of his or her religious practices. Penal populism still remains a serious threat also on the level of executive penal law. This means that statutory (written) law in the form of an act should be the minimal level of regulation (a legal act one level below the Constitution).

It is clear that the public opinion must not be totally rejected. Still, scholars should strive to make the public look at the issue of imprisonment in a more open way - recognizing that human rights, including freedom of religion and its conflict-free manifestation, are a humanistic value that cannot be lost (even) in the prison. Polish studies show that Poles obtain knowledge on crime and the functioning of the judicial system mainly from the mass media (Szymanowski 2012: 202; Pieniążek and Stefaniuk 2014: 208). A rational state should use this path to achieve a rational effect. Bearing in mind that statutory law also shapes public views ('Law is both a product of social and power relations and a tool for challenging and reshaping those relations'; World Bank 
Group 2017), the call for clear, transparent and precise executive law becomes all the more legitimate.

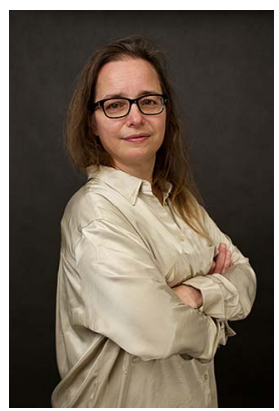

Olga Sitarz is an associate professor at the University of Silesia in Katowice (Poland), and a specialist in criminal law, criminology and executive penal law. She is a former judge of the District Court in Katowice, an active mediator at the Silesian Centre for Arbitration and Mediation and the head of the research project: 'The standards of respect the religious rights of persons detained in prisons, detention centers, educational and correctional centers for juveniles', financed by the National Science Centre (Poland). Her latest publications include the articles, 'Protection of Christian values - penal populism or a rational decision on criminalization?' (2021) and 'Ratio legis of criminalization of the offence against religious feelings (and blasphemy)' (2021), as well as a number of book chapters.

\section{Anna Jaworska-Wieloch is an assistant professor at the University of Silesia in Katowice (Poland), and a specialist in criminal law and executive penal law. She was a social probation officer in criminal cases and currently she is a judge of the District Court

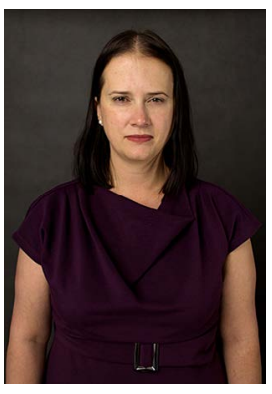 in Gliwice. Her doctoral dissertation is a dogmatic and empirical study of the reasons for the revocation of conditional release in Poland (2016).}

Jakub Hanc is a Ph.D. student at the Doctoral School University of Silesia in Katowice (Poland). The focus of his research is criminal law and its history as well as medical law.

Photos:

Małgorzata Dymowska

\section{References}

Babbie, Earl. 2016. The Practice of Social Research (Boston: Cengage Learning).

Batorski, Dominik, and Marta Olcoń-Kubicka. 2006. 'Prowadzenie badań przez internet podstawowe zagadnienia metodologiczne', Studia Socjologiczne 182(3): 99-132.

Becci, Irene, and Joshua Dubler. 2017. 'Religion and religions in prisons: observations from the United States and Europe', Journal for the Scientific Study of Religion, 56(2): 241-7, doi: <https://doi.org/10.1111/jssr.12352>.

Beckford, Arthur James, and Sophie Gilliat. 2005. Religion in Prison. Equal Rites in a Multi-Faith Society (Cambridge University Press).

Centrum Badania Opinii Społecznej. 2020. 'Religijność Polaków w ostatnich 20 latach', Komunikat z Badań 63, <https://cbos.pl/ SPISKOM.POL/2020/K_063_20.PDF> (accessed 19.7.2021).

Creswell, John Ward, and John David Creswell. 2018. Research Design: Qualitative, Quantitative, and Mixed Methods Approaches (Los Angeles, CA: Sage Publishing).

Cullen, Francis Thomas, Bonnie Sue Fisher, and Brandon K. Applegate. 2000. 'Public opinion about punishment and corrections', Crime and Justice 27: 1-79, doi: <https:// doi.org/10.1086/652198>.

Hagan, Frank Edward. 2018. Research Methods in Criminal Justice and Criminology (New York: Pearson).

Hirschberger, Jeanne. 2020. " "Imprisonment is expensive": breaking down the costs and impacts globally', Penal Reform International 24.7.2020, <https://www.penalreform.org/blog/imprisonment-is-expensivebreaking-down-the-costs-and/> (accessed 30.7.2021).

Hucał, Michał. 2016. 'Wolność sumienia i wyznania osób pozbawionych wolności w orzecznictwie ETPCz', in Wolność sumienia i religii osób pozbawionych wolności. Aspekty prawne $i$ praktyczne, eds. Jerzy Nikołajew and Konrad Walczyk (Warszawa: Wydawnictwo Diecezji Siedleckiej Unitas), 191-201.

Human Rights and Prisons. A Pocketbook of International Human Rights Standards for Prison Officials. 2005. <https://www.un.org/ ruleoflaw/files/training 11 Add 3 en.pdf $>$ (accessed 30.7.2021). 
Kaczmarczyk, Stanisław. 2018. 'Zalety i wady metod zbierania danych przez internet $\mathrm{w}$ badaniach marketingowych', Zeszyty Naukowe Politechniki Śląskiej. Organizacja $i$ Zarządzanie 129: 187-200.

Kapotas, Panos. 2017. 'The saga of Anders Breivik's prison conditions puts European democracy in the spotlight', The Conversation 2.3.2017, <https://theconversation. $\mathrm{com} /$ the-saga-of-anders-breiviks-prison-conditions-puts-european-democracy-in-the-spotlight-73917> (accessed 19.7.2021).

Kwieciński, Adam. 2015. 'Podstawy prawne realizacji prawa do wolności religijnej $\mathrm{w}$ warunkach izolacji penitencjarnej. Rozważania na marginesie dyskusji o zjawisku multikulturowości populacji więziennej, Przegląd Prawa $i$ Administracji $100(\mathrm{C} / 2)$ : 251-64.

Lelental, Stefan. 2001. Kodeks karny wykonawczy. Komentarz (Warszawa: C. H. Beck).

Martínez-Torrón, Javier. 2012. 'Freedom of religion in the European Convention on Human Rights under the influence of different European traditions', in Universal Rights in a World of Diversity. The Case of Religious Freedom, eds. Mary Ann Glendon and Hans Friedrich Zacher (Vatican City: The Pontifical Academy of Social Sciences), 329-55.

Miszczak, Agata, and Joanna Walasek. 2013. 'Techniki wyboru próby badawczej', Obronność: Zeszyty Naukowe Wydziału Zarzadzania i Dowodzenia Akademii Obrony Narodowej 2(6): 100-8.

Newsbeezer.com 2018. "Polish murderers" tell the story of "Madzia's mother" from Sosnowiec. The premiere on March 28th', Newsbeezer.com 21.3.2018, <https://newsbeezer. $\mathrm{com} /$ polandeng/polish-murderers-tell-thestory-of-madzias-mother-from-sosnowiecthe-premiere-on-march-28th/> (accessed 19.7.2021)

Nikołajew, Jerzy. 2012. Wolność sumienia i religii skazanych $i$ tymczasowo aresztowanych (Lublin: Wydawnictwo Katolickiego Uniwersytetu Lubelskiego).

Nikołajew, Jerzy. 2013. 'Reguły minimalne i europejskie reguły więzienne a prawo więźniów do wolności sumienia i religii $\mathrm{w}$ Polsce, Studia z Prawa Wyznaniowego 16: 111-35.
Nowicki, Marek. 2017. Wokół Konwencji Europejskiej. Komentarz do Europejskiej Konwencji Praw Człowieka (Warszawa: Wolters Kluwer).

Pieniążek, Antoni, and Małgorzata Stefaniuk. 2014. Socjologia prawa. Zarys wykładu (Warszawa: Wolters Kluwer).

Płatek, Monika. 2008. 'Europejskie Reguły Więzienne z 2006 r., Państwo i Prawo 2: 3-17.

Płatek, Monika. 2009. 'Wybrane zasady kodeksu karnego wykonawczego z 1997 r. W świetle Europejskich Reguł Więziennych $\mathrm{z}$ 11 stycznia 2006 r., in X lat obowiazzywania Kodeksu Karnego Wykonawczego, eds. Stefan Lelental and Grażyna Szczygieł (Białystok: Temida 2), 105-28.

Podgórska, Joanna. 2021. 'Pusty Kościół. Dlaczego przeżywa tak głęboki kryzys?', Polityka 4.3.2021, <https://www.polityka.pl/tygodnikpolityka/spoleczenstwo/ 2106635,1 ,pusty-kosciol-dlaczego-przezywa-tak-gleboki-kryzys.read> (accessed 19.7.2021).

Report 2020. 'Raport o przestrzeganiu wolności religijnej na świecie - Polska, $<$ https://pl.usembassy.gov/wp-content/ uploads/sites/23/irfr202opl.pdf> (accessed 30.7.2021),

Raza, Farrah. 2020. 'Limitations to the right to religious freedom: rethinking key approaches', Oxford Journal of Law and Religion 9(3): 435-62, doi: <https://doi. org/10.1093/ojlr/rwaa025>.

Rubin, Ashley T. 2019. 'History of the prison', in The Handbook of Social Control, ed. Mathieu Deflem (Hoboken, NJ: Wiley Blackwell), 277-92, doi: <https://doi. org/10.1002/9781119372394.ch20>.

Siemaszko, Andrzej, Paweł Ostaszewski, and Joanna Klimczak. 2018. Badanie poparcia dla zaostrzenia polityki karnej. Wyniki trzech sondaży opinii publicznej (Warszawa: Instytut Wymiaru Sprawiedliwości).

Sitarz, Olga, and Anna Jaworska-Wieloch. 2017. 'Prawo do praktyk religijnych osób osadzonych $\mathrm{w}$ areszcie śledczym i odbywających karę pozbawienia wolności w teorii i praktyce penitencjarnej', Archiwum Kryminologii 39: 117-48, doi: <https://doi.org/10.7420/ $\mathrm{AK} 2017 \mathrm{D}>$. 
Sitarz, Olga, Anna Jaworska-Wieloch, Jakub Hanc. 2021. 'Nowelizacja art. $106 \$ 1$ k.k.w. i art. 110a $\$ 1$ kodeksu karnego wykonawczego', Prawo w Działaniu 45: 141-8, doi: $<$ https://doi.org/10.32041/pwd. 4509>.

Sitnik, Katarzyna, and Kamila Mrozek. 2011. 'Prawo skazanych do korzystania z wolności religijnej', Przegląd Prawa Konstytucyjnego 8(4): 205-24, doi: <https://doi. org/10.15804/ppk.2011.04.10>.

Slotte, Pamela. 2020. 'Religion and human rights: ambiguities and ambivalences of freedom, in Freedom of Religion. An Ambiguous Right in the Contemporary European Legal Order, eds. Hedvig Bernitz and Victoria Enkvist (Oxford: Hart Publishing), 3-16.

Snyder, Donald. 2021. 'A "time of crisis" for Poland's Catholic Church', National Catholic Reporter 15.1.2021, <https://www.ncronline.org/news/accountability/time-crisis-polands-catholic-church $>$ (accessed 30.7.2021).

Sobczak, Witold. 2012. Art. 18 ['Wolność myśli, sumienia i religii'], in Międzynarodowy pakt praw obywatelskich (osobistych) $i$ politycznych. Komentarz, ed. Roman Wieruszewski (Warszawa: Wolters Kluwer), 419-60.

Szymanowski, Teodor. 2012. Przestępczość i polityka karna $w$ Polsce $w$ świetle faktów $i$ opinii społeczeństwa $w$ okresie transformacji (Warszawa: Wolters Kluwer).

Szymanowski, Teodor, and Jerzy Migdał. 2014. Prawo karne wykonawcze i polityka penitencjarna (Warszawa: Wolters Kluwer).

Temperman, Jeroen. 2018. 'Freedom of/for/ from/within religion in prison. A taxonomy of the Strasbourg jurisprudence, in Religious Freedom and the Law. Emerging Contexts for Freedom for and from Religion, eds. Brett Gilbert Scharffs, Asher Maoz, and Ashley Isaacson Woolley (London: Routledge), 144-53.

Tiedemann, Paul. 2012. Religionsfreiheit. Menschenrecht oder Toleranzgebot? Was Religion ist und warum sie rechtlichen Schutz verdient (Berlin: Springer-Verlag).

Urbaniak-Zając, Danuta. 2018. 'O łączeniu badań ilościowych i jakościowych - oczekiwania i wątpliwości', Przegląd Badań Edukacyjnych 26(1): 121-38, doi: <https://doi. org/10.12775/PBE.2018.007>.
Wilcox, Clyde, and Rachel Goldberg. 2002. 'Public opinion on Church-State issues in a changing environment', Journal for the Scientific Study of Religion 41(2): 369-76.

World Bank Group. 2017. 'The role of law', in World Bank Group. World Development Report 2017. Governance - The Law (Washington: International Bank for Reconstruction and Development/The World Bank), 83-101.

Wozniak, Kevin H. 2014. 'American public opinion about prisons', Criminal Justice Review 39(3): 305-24, doi: <https://doi. org/10.1177/0734016814529968>. 